\title{
EFEKTIVITAS UJIAN KOMPREHENSIF DALAM MENINGKATKAN KOMPOTENSI MAHASISWA PRODI ILMU AQIDAH
}

\author{
Rahmi Damis \\ Aqidah dan Filsafat Islam \\ Fakultas Ushuluddin, Filsafat dan Politik \\ UIN Alauddin Makassar \\ E-mail: rahmi.damis@uin-alauddin.ac.id
}

\begin{abstract}
Ujian komprehensip merupakan salah satu bentuk ujian yang harus dilalui oleh mahasiswa Prodi Ilmu Akidah yang pelaksanaannya melalui syarat-syarat; Mahasiwa mengecek nilai, kemudian melakukan tes baca tulis al-Qur'an dan mendapat keterangan dari pembimbing Skripsi.

Kendala yang dihadapi oleh mahasiswa dalam ujian komprehensif kurang mengusai materi yang akan diujikan. Kesulitan menentukan waktu yang tepat untuk ujian, karena harus menyesuaikan waktu penguji, dan kurangnya referensi tentang mata kuliah yang diujikan.

Adapun manfaat yang diperoleh mahasiswa adalah; Menambah pengetahuan dan wawasan mahasiswa tentang materi-materi mata kuliah kompotensi Prodi. Menguji kemampuan yang dimiliki oleh mahasiswa, sekaligus dimaksudkan mengetahui kompotensi yang dimiliki oleh mahasiswa yang akan menjadi sarjana atau menyelesaikan studinya.
\end{abstract}

\section{Keywords;}

Komprehensif, Mahasiswa, Prodi

\section{A. PENDAHULUAN}

Prodi Ilmu Aqidah yang berada di Fakultas Ushuluddin merupakan salah bagian dari UIN Alauddin, turut melakukan pembenahan diri dalam menciptakan anak didik yang professional. Hal tersebut, tergambar dalam tujuan umumnya adalah melahirkan dan membina sarjana-sarjana muslim yang memiliki kompetensi akademik dalam bidang pemikiran Islam (teologi Islam, filasafat Islam, dan tasawuf), berakhlak mulia, terampil dalam menerapkan dan mengembangkan pengetahuan dan keahlian dalam konteks akademik dan masyarakat Indonesia kontemporer. Begitu pula dengan tujuan khususnya yaitu:

1. Melahirkan sarjana dengan kemampuan penalaran, analisa dan sintesa dan tajam berkaitan dengan konsep-konsep pemikiran Islam, di bidang teologi, aqidah, dan tasawuf.

2. Mampu merumuskan pemecahan masalah-masalah sosioreligius dalam bentuk konsep-konsep pemikiran Islam yang kreatif, inovatif, dan kompatibel dengan tuntutan dan kebutuhan masyarakat muslim kontemporer. 
3. Mampu menghasilkan karya-karya intelektual dalam rana pemikiran Islam berdasarkan perspektif aqidah dan teologi Islam dan tasawuf.

4. Memiliki kompetensi besar untuk berprofesi dalam bidang pemikiran Islam baik dalam konteks akademik maupun sosial, budaya dan ekonomi. ${ }^{1}$

Seorang sarjana di bidang ilmu aqidah minimal ia menguasai mata kuliah keahlian mereka sebagai bukti dan tanggung jawab moral sebagai sarjana Ilmu Aqidah, yang kemudian digunakan dalam menghadapi masalah-masalah yang muncul di masyarakat terkait dengan persoalan aqidah. Dengan kemampuan menyelesaikan persoalan-persoalan yang muncul di masyarakat merupakan suatu sosialisasi dan harapan yang cukup baik bagi Prodi Ilmu Aqidah, outputnya dapat memperkenalkan Prodinya melalui kompotensi keilmuan yang dimiliki.

Jika melihat waktu yang diberikan kepada mahasiswa dalam mengikuti ujian komprehensif, tentunya dapat diprogramkan dengan baik dan tidak akan terjadi pengulangan, karena waktu pelaksanaan dibukaa setiap saat. Sementara kenyataan bagi mahasiswayang ingin ikut ujian komprehensif, pada umumnya mereka mendaftar menjelang wisuda, sehingga kesiapan untuk belajar dengan baik tidak dapat dilakukan. Selain itu, mereka secara bersamaan ketiga mata kuliah yang diujikan dalam ujian komprehensif $^{2}$ diprogramkan secara bersamaan.

Berdasarkan uraian tersebut di atas, masalah pokok dalam penelitian ini adalah Bagaimana efektivitas ujian komprehensif dalam meningkatkan kompotensi Mahasiswa Jurusan Aqidah Filsafat Prodi Ilmu Aqidah ? Untuk menemukan jawaban yang baik terhadap masalah pokok maka dirumuskan sub masalah sebagai berikut:

1. Bagaimana pelaksanaan ujian komprehensif bagi mahasiswa Jurusan Aqidah Filsafat Prodi Ilmu Aqidah?

2. Bagaimana kendala yang dihadapi oleh mahasiswa dalam ujian komprehensif ?

3. Bagaimana manfaat bagi mahasiswa Jurusan Aqidah dan Filsafat Prodi Ilmu Aqidah ?

Adapun tujuan penelitian adalah:

1. Mengetahui efektivitas pelaksanaan ujian komprehensif bagi mahasiswa Jurusan Aqidah dan Filsafat Prodi Ilmu Aqidah.

2. Mengungkapkan kendala yang dihadapi dalam pelaksanaan unjian Komprehensif bagi mahsiswa Jurusan Aqidah dan Filsafat Prodi Ilmu Aqidah.

3. Mengungkapkan manfaat yang diperoleh bagi mahasiswa Jurusan Aqidah dan Filsafat Prodi Ilmu Aqidah.

Sedang kegunaan ilmiah yang diharapkan; dapat memberi manfaat sebagai wadah saling bertukar informasi dan gagasan untuk pengembangan dan penguatan Jurusan Aqidah dan Filsafat Prodi Ilmu Aqidah. Kegunaan praktis, adalah dengan mengetahaui efektivitas pelaksanaan ujian komprehensif dapat memberikan kemudahan

\footnotetext{
${ }^{1}$ Lihat Borang akreditasi Prodi Ilmu aqidah, h. 36-37

${ }^{2}$ Mata Kuliah Ujian komprehensif adalah; Pengantar Filsafat, Teologi Islam dan Tafsir Hadis
} 
bagi mahasiswa Jurusan Aqidah dan Filsafat Prodi Ilmu Aqidah dalam melaksanakan ujian komprehensif.

Adapun landasan teori dalam penelitian ini adalah al-Qur'an, mengemukakan ada tiga komponen yang digunakan dalam memperoleh ilmu pengetahuan, yaitu; pemndengaran, penglihatan, dan hati, Q.S. al-Nahl/16; 78.

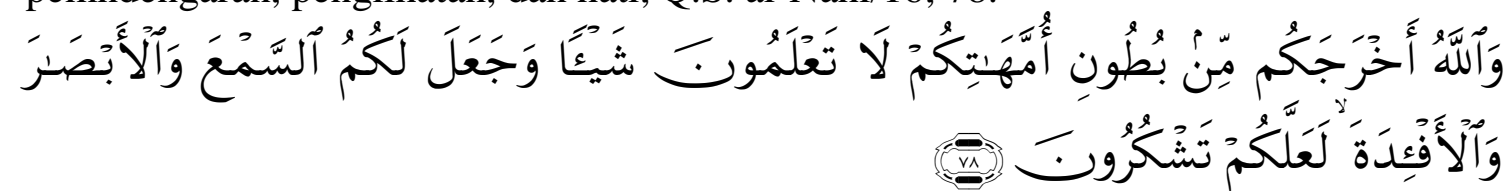

Terjemahnya:

Dan Allah mengeluarkan kamu dari perut ibumu dalam keadaan tidak mengetahui sesuatupun, dan dia memberi kamu pendengaran, penglihatan dan hati, agar kamu bersyukur.

Al-Syaukani menegemukakan bahwa Allah menjadikan untukmu pendengaran, penglihatan, dan hati agar kamu menggunakan untuk memperoleh ilmu pengetahuan, yang sebelumnya amu tidak memilikinya, dan kamu melakukan sesuatu berdasarkan tuntunan pengetahuan tersebut, agar kamu bersyuku kepada Tuhan dengan menjalankan ibadah kepada-Nya dan menunaikan hak-hak-Nya. ${ }^{3}$

Abd. Muin Salim mengemukakan tiga metode dalam memperoleh Ilmu pengetahuan menurut petunjuk al-Qur'an;

1. Pengetahuan olahan (ilmu kasbiyun), yaitu pengetahuan yang diperoleh manusia bersumber dari luar dirinya melalui pengalaman hidup ataupun dengan usaha yang disengaja.

2. Pengetahuan limpahan (ilmu wagabiyyun), yaitu pengetahuan yang diperoleh manusia berswumber dari luar dirinya sebagai pemberian Tuhan kepadanya baik untuk kepentingannya sendiri maupun untuk kepentingan kemanusiaan dan lingkungannya, misalnya pengetahuan berupa ilham atau wahyu.

3. Pengetahuan rasa (ilmu syu'uriyyun), yaitu pengetahuan yang diperoleh seseorang berdasrkan potensi jiwaa untuk menanggapi dan memahami keadaan dirinya pada satu saat. Pengetahuan ini pada hakekatnya merupakan kesadaran diri terhadap keberadaab diri sendiri yang muncul dari dalam. ${ }^{4}$

Teori pendidikan mengemukakan beberapa aliran yang dapat meningkatkan pengetahuan manusia, yakni berdasarkan apa yang diperoleh manusia sejak lahir, seperti yang diuraikan aliran Emperisme: perkembangan seorang dapat ditentukan oleh lingkungan atau pendidikan dan pengalaman yang diterima sejak lahir. Begitu pula aliran Naturalisme menilai pada dasarnya anak sejak anak dilahairkan adalah baik, sedang perkembangannya ditentukan oleh pendidikan yang diterima atau yang mempengaruhinya. Seperti yang dikemkakan oleh J.J Rousseau: Semua anak adalah

\footnotetext{
${ }^{3}$ Muhammad bin Ali bin Muhammad, Irsyad al-Fuhuli Ila Tahqiq al-Haqq min Ilmi al-Usuli (Beirut: Dar al-Fikr, t.t.), h. 5.

${ }^{4}$ Abd. Muin Salim, Beberapa Aspek Metodologi Tafsir al-Qur'an (Ujung Pandang: Lembaga Studi Kebudayaan Islam, 1990), h. 24-25.
} 
baik pada waktu datang dari tngan Sang Pencipta, tetapi semua menjadi rusak di tangan manusia. $^{5}$

Sebaliknya aliran Nativisme Perkembangan manusia ditenukan oleh faktorfaktor yang dibawa manusia sejak lahir; pembawaan yang terdapat pawa waktu dilahirkan itulah yang menentukan hasil perkembanagan. ${ }^{6}$ Jadi pendidikan tidak dapat mengubah sifat-sifat pembawaan.

Adapula yang memadukan kedua aliran yang bertentangan tersebut, yaitu aliran Konvergensi yang berpendapat: pembawaan dan lingkungan kedua-keduanya menentukan perkembangan manusia. ${ }^{7}$

Dalam pelaksanaan penelitian digunakan beberapa metode:

$>$ Jenis dan Lokasi Penelitian

Penelitian deskriptif kualitatif adalah penelitian yang memberikan gambaran tentang situasi dan kejadian secara faktual dan sistimatis mengenai faktor-faktor, sifat-sifat, serta hubungan antara fenomena yang dimiliki untuk melakukan akumulasi dasar-dasarnya saja. ${ }^{8}$ Berdasar hal tersebut, maka jenis penelitian ini adalah penelitian diskriptif kualitatif, walaupun penelitian ini adalah penelitian, tetapi juga terkait dengan beberapa literatur.

Adapun lokasi penelitian yaitu mahasiswa Prodi Ilmu Aqidah Jurusan Aqidah dan Filsafat Fakultas Ushuluddin dan Filsafat UIN Alauddin Makassar. karena untuk memperoleh data yang dibutuhkan tentunya memilih lokasi yang mudah dijangkau, agar dapat mengamati obyek yang akan diteiti setiap saat. Hal ini sejalan dengan pendapat Spradley yang mengemukakan bahwa apabila ingin memperoleh hasil penelitian yang lebih baik maka dalam memilih dan menentukan lokasi penelitian harus mempertimbangkan beberapa aspek sebagai berikut: a) sederhana, b) mudah memasukinya, c) tidak begitu kentara dalam melakukan penelitian, d) mudah memperoleh izin. ${ }^{9}$

Mahasiswa yang dijadikan sampel penelitian, mereka yang sudah melalui ujian komprehensif, baik dari Prodi Ilmu Aqidah itu sendiri maupun dari Prodi Aqidah dan Filsafat.

$>$ Metode Pendekatan

Oleh karena penelitian ini berada pada tataran UIN Alauddin yang menitik beratkan pendekatan dalam bidang keilmuan, penulis menggunakan beberapa pendekatan yaitu; Pendekatan Filosofis, Pendekatan Teologis Normatif.dan Pendekatan Faedagogik.

$>$ Sumber Data

5 M. Ngalim Purwanto, Ilmu Pendidikan Teroritis dan Praktis (Bandung: PT Remaja Rosdakarya, 2009), h. 59.

${ }_{6}$ M. Ngalim Purwanto, Ilmu Pendidikan Teroritis dan Praktis, h. 59

${ }^{7}$ M. Ngalim Purwanto, Ilmu Pendidikan Teroritis dan Praktis, h. 60

${ }^{8}$ Lihat Lexy J. Moleong, Metode Penelitian Kualitatif (Cet.VIII; Bandung: PT. Remaja Rosdakarya, 2000), h. 6.

${ }_{9}^{9}$ Lihat James P. Spradley, Participation Observation (New York: Holt, Rinehart and Winston, 1990),h. $46 \& 51$. 
Sumber data yang digunakan dalam penelitian ini dapat diklasifikasikan sebagai berikut: Data primer yaitu terdiri dari informan utama yaitu para mahasiswa Prodi Ilmu Aqidah melalui wawancara dan observasi. Data sekunder diambil dari dokumen tertulis yang di Prodi.

Metode Pengumpulan Dan Pengolahan Data

Mengawali uraian ini dikemukakan dasar metode yang digunakan, yaitu menurut Ine I Amiran Yousda dan Zainal Arifin bahwa metode pengumpulan data dalam penelitian kualitatif adalah observasi dan wawancara, angket, tes psikologi dan studi dokumentasi. ${ }^{10}$ Berdasar dengan jenis, ciri-ciri, dan sumbernya penelitian ini maka pandangan Ine tersebut dijadikan rujukan utama, sekalipun hanya beberapa saja metode yang dikemukakan digunakan dalam penelitian ini, yaitu; Metode interview atau wawancara dan obsevasi .

Sutrisno Hadi mengatakan bahwa wawancara adalah penelitian yang berlangsung secara lisan antara dua orang atau lebih dalam bentuk tatap muka, mendengarkan secara langsung mengenai informasi-informasi atau keteranganketerangan. ${ }^{11}$ Selain itu digunakan pula observasi, karena peneliti merupakan penguji komprehensif untuk mahasiswa Ilmu Aqidah..

Data pokok yang dihadapi dalam penelitian ini terdiri atas ajaran-ajaran tarekat Muktabarah yang diperoleh dari beberapa literatur dan hasil wawancara serta hasil pengamatan yang bersifat pernyataan, maka dalam pengolahan data tersebut menggunakan metode kualitatif.

\section{B. Hasil Penelitian}

\section{Posisi Ujian Komprehensif}

UIN Alauddin Makassar adalah salah satu lembaga pendidikan tinggi yang mengkaji ilmu-ilmu keislaman di Makassar Sulawesi Selatan. Saat ini UIN Alauddin Makassar telah menyelenggarakan beberapa pendidikan akademik setingkat sarjana (S1) dan pascasarjana (S2) dan (S3). Salah satu Prograam Studi yang diselenggarakan di UIN Alauddin Makassar adalah Prograam Studi Ilmu Aqidah yang berada di Jurusan Aqidah Filsafat Fakultas Ushuluddin, Filsafat dan Politik.

Dalam memberikan arah pelaksanaan Prograam Studi Ilmu Aqidah maka dirumuskan Visi Prograam Studi Ilmu Aqidah yaitu unggul dalam kajian ilmu Aqidah yang transformative-humanistik dan terintegrasi dengan nilai-nilai kearifan lokal dan keindonesiaan. Sedangkan misinya adalah: a) Melahirkan Sarjana Muslim yang memiliki kompetensi akademik dalam bidang Ilmu Akidah. b) Memelopori penciptaan komunitas akademik yang mampu memberikan tanggapan intelektual, moral dan spiritual terhadap isu-isu pemikiran Islam kontemporer; c) Menunjang proses pendirian pusat/lembaga studi riset, dan pengembangan filsafat Islam yang lebih komprehensif dan kompetitif

\footnotetext{
${ }^{10}$ Ine I Yousda Amiran \& Zainal Arifin, Penelitian dan Statistik Pendidikan (Jakarta: PT. Bumi Restu, Aksara), h. 45.

${ }^{11}$ Lihat Surtrisno Hadi, Metodologi Reseach (Jakarta: UGM Press, 1980), h. 113.
} 
Untuk memperjelas visi dan misi Prodi Ilmu Aqidah, dirumuskanlah tujuan Prograam Studi Ilmu Aqidah yaitu: a) Melahirkan sarjana dengan kemampuan penalaran, analisa dan sintesa dan tajam berkaitan dengan konsep-konsep pemikiran Islam, di bidang teologi, filsafat, dan tasawuf. b). Mampu merumuskan pemecahan masalah-masalah sosioreligius dalam bentuk konsep-konsep pemikiran Islam yang kreatif, inovatif, dan kompatibel dengan tuntutan dan kebutuhan masyarakat muslim kontemporer. c). Mampu menghasilkan karya-karya intelektual dalam rana pemikiran Islam berdasarkan perspektif filsafat dan teologi Islam dan tasawuf. d). Memiliki kompetensi besar untuk berprofesi dalam bidang pemikiran Islam baik dalam konteks akademik maupun social, budaya dan ekonomi.

Secara spesifikasi Prodi Ilmu Akidah akan melahirkan lulusan yang memenuhi kreteria sebagai berikut:

\section{a. Pengetahuan dan Pemahaman (Knowledge and Understanding)}

Kompetensi lulusan Jurusan Aqidah dan Filsafat memiliki keahlian (konsentrasi) sebagai berikut:

1) Menguasai seluk beluk pemikiran filsafat dan Aqidah yang berkembang di seluruh dunia belahan Barat dan Islam

2) Mengerti dan memahami asas Aqidah, filsafat, teologi dan tasawuf dan mampu mengaplikasikan dalam kehidupan

3) Lulusan memiliki kepribadian dan integritas yang menjunjung tinggi nilai-nilai agama

4) Mampu bekerja sama secara sosial baik dalam ranah internal religious maupun melintasi-batas (Passing over)

5) Profesional dalam pemikiran Islam dan dengan kemampuan yang komprehensifnya mampu bersaing dalam dunia kerja. ${ }^{12}$

\section{b. Pengetahuan dan Pemahaman (Knowledge and Understanding)}

Kompetensi lulusan Jurusan Aqidah dan Filsafat memiliki keahlian (konsentrasi) sebagai berikut:

1) Menguasai seluk beluk pemikiran filsafat dan Aqidah yang berkembang di seluruh dunia belahan Barat dan Islam.

2) Mengerti dan memahami asas Aqidah, filsafat, teologi dan tasawuf dan mampu mengaplikasikan dalam kehidupan

3) Lulusan memiliki kepribadian dan integritas yang menjunjung tinggi nilai-nilai agama

4) Mampu bekerja sama secara sosial baik dalam ranah internal religious maupun melintasi-batas (Passing over)

5) Profesional dalam pemikiran Islam dan dengan kemampuan yang komprehensifnya mampu bersaing dalam dunia kerja

\section{c. Keterampilan Intelektual (Intellectual Skill)}

1) Profesional dalam berpikir, berpendapat dan bertindak

${ }^{12}$ Spesifikasi Prodi Ilmu Aqidah, h. 5 
2) Mampu memetakkan masalah sosial secara proporsional sesuai dengan kaidahkaidah filsafat dan doktrin Islam..

3) Menguasai konsep pemikiran Barat dan timur dalam dimensi Aqidah, filsafat, teologi dan Tasawuf secara Hierarkis sampai era kontemporer.

4) Menjadi pionir dan manager ulung dalam mengelola kehidupan bermasyarakat secara damai dan tentram yang berperadaban tinggi. ${ }^{13}$

\section{d. Keterampilan Managerial dan Praktis (Managerial Skill and Practical Skill)}

1) Menguasai secara aktif mengikuti perkembangan Aqidah, teologi dan tasawuf mulai dari zaman Kuno sampai saat ini.

2) Menguasai metode, sejarah, tokoh teologi, tasawuf.

3) Menguasai sejumlah deretan Teolog dan sufi dengan pemikirannya masingmasing dan dapat mentransfer ide-ide tersebut kepada orang lain.

4) Mampu berkomunikasi dan mendialog konsep Ilmu Aqidah secara efektif dalam menghadapi masalah sosio-religio dengan professional dan proporsional.

5) Mampu mengembangkan diri dalam berfikir radiks, logis dan analitis untuk menyelesaikan masalah-masalah yang dihadapi secara profesional.

6) Mampu mengamalkan konsep-konsep Aqidah Islam dalam dimensi teologi dan tasawwuf.

7) Mampu bekerja sama dan menyesuaikan diri dengan cepat di lingkungan masyarakat umum.

\section{e. Keterampilan Emosional dan spiritual (Emotional Skill and spritual)}

1) Menjunjung tinggi norma, tata-nilai, dan doktrin keagamaan secara tanggung jawab dan profesional.

2) Mampu berinteraksi dengan perkembangan sains dan teknologi sebagai media untuk komunikasi secara efektif

3) Mengerti dan memiliki kearifan lingkungan, sosial dan yang berkesinambungan.

4) Mampu mengembangkan diri secara bijak, berpikir rasional, memiliki rasa kerahiman dan bertindak professional dan proporsional. ${ }^{14}$

Berdasarkan Kurikulum Tahun 2010, untuk memperoleh gelar sarjana, seorang mahasiswa harus menyelesaikan minimal 144 SKS yang terdiri dari 137 SKS untuk kurikulum inti, 3 sks mata kuliah komprehensif dan 4 sks mata kuliah pilihan. Pada akhir proses pembelajaran, mahasiswa diwajibkan membuat tugas akhir berbentuk skripsi (6 sks) yang dibimbing oleh pembimbing ahli dan dipertahankan di depan penguji untuk menentukan kelulusan.

Dalam penentuan nilai akhir, ujian komprehensif termasuk sangat menentukan karena memiliki nilai SKS 3 dan tidak bisa ujian akhir atau Skripsi jika tidak lulus ujian komprehensif. Nilai 3 SKS tersebut, masuk dalam hitungan jumlah SKS yang akan diselesaikan oleh Mahasiswa Ilmu Aqidah yaitu 150 SKS, sehingga jika belum lulus ujian komprehensif, niscaya tidak bisa selesai atau munaqasyah.

\footnotetext{
${ }^{13}$ Spesifikasi Prodi Ilmu Aqidah, h. 5

${ }^{14}$ Spesifikasi Prodi Ilmu Aqidah, h. 6.
} 
1. Pelaksanaan ujian komprehensif meliputi:

a. Pendaftaran ujian komprehensif

Pendaftaran ujian komprehensif tidak ada pembatasan artinya dibuka setiap saat sehingga mahasiswa bebas memilih kapan mereka siap dan mendaftar. Tujuannya tidak lain mempermudah mahasiswa dalam menyelesaikan studi sekaligus menjadi sarana membekali mereka sebelum meninggalkan kampus terutama yang terkait dengan mata kuliah keahlian mereka. Kapan mereka ujian Komprehensif sepenuhnya ditentukan oleh mahassiwa itu sendiri. Hal ini dilakukan dengan harapan ada kemudahan, sehingga saat mereka ditanya tentang masalah waktu pelaksanaan ujian komprehensif mereka setuju, hal ini dapat dilihat dalam table sebagai berikut:

Tabel 1

Apakah saudara setuju dengan waktu pelaksanaan ujian komprehensif

\begin{tabular}{|l|c|c|c|}
\hline No. & Pilihan Jawaban & Frekuensi & Presentase (\%) \\
\hline 1. & Ya & 15 & $100 \%$ \\
2. & Tidak & - & $0 \%$ \\
3. & Kurang setuju & - & $0 \%$ \\
& & & $100 \%$ \\
\hline
\end{tabular}

Meskipun mereka setuju terhadap waktu pleaksanaan ujian komprehensif tersebut, akan tetapi tidak berarti bebas mahasiswa mendaftar begitu saja, melainkan harus memenuhi syarat sebagai berikut:

- Ada keterangan bebas semester, artinya semua mata kuliah mulai dari semester I sampai VII harus lulus dan nilainya sudah masuk di staf Jurusan Aqidah Filsafat.

- Harus ada keterangan bisa membaca dan menulis al-Qur'an

- Harus ada keterangan dari Pembimbing skripsi, bahwa skripi mahasiswa yang akan unjian komprehensif sudah dikonsultasikan.

- Melampirkan bukti pembayaran semester berjalan. ${ }^{15}$

Sesungguhnya syarat tersebut, sangat mudah bagi mahasiswa, karena dengan melapor kepada staf jurusan syarat tersebut, akan disiapkan termasuk persetujuan dari dosen pembimbing. Mahasiswa hanya meminta tanda tangan dari dosen pembimbingnyam, jika memang skripsinya sudah dikonsultasikan. Kemudahan tersebut dapat dilihat dalam tabel sebabagi berikut:

Tabel 2

Apakah syarat ujian komprehensif menyulitkan mahasiswa

\begin{tabular}{|l|c|c|c|}
\hline No. & Pilihan Jawaban & Frekuensi & Presentase (\%) \\
\hline 1. & Ya & - & $0 \%$ \\
2. & tidak & 15 & $100 \%$ \\
3. & Kurang setuju & - & $0 \%$ \\
\hline
\end{tabular}

15 Wawancara dengan staf Jurusan Aqidah Filsafat Fakultas ushuluddin dan Filsafat UIN Alauddin, Hari Selasa 19 Agustus 2014. 


\begin{tabular}{|l|l|l|l|}
\hline & & & \\
\hline & Jumlah & 15 & $100 \%$ \\
\hline
\end{tabular}

Dengan melihat syarat yang harus dipenuhi oleh mahasiswa tersebut di atas, menunjukkan unjian komprehensif dipersiapkan mengisi mahasiswa sebelum menjadi sarjana, karena mata kuliah yang akan dujikan dikomprhensif adalah mata kuliah yang termasuk keahlian mereka, sehingga saat menjadi sarjana ada bekal mereka, karena boleh jadi apa yang diberikan saat semester awal belum tentu mereka ingat.

Syarat tersebut bagi mahasiswa juga sudah dianggap cukup dan dengan sendirinya dapat terpenuhi jika mereka sungguh-sungguh mengikuti kuliah, kecuali baca tulis alQur'an. Akan tetapi sejak awal sudah disampaikan bahwa pada akhir penyelesaian studi akan diadakan tes baca tulis al-Qur'an, sehingga harus mulai dari awal dipersiapkan jika memang masih belum lancar membaca al-Qur'an. Itulah sebabnya mahasiswa melihat syarat tersebut sudah tepat bagi mereka seperti yang terlihat dalam tabel sebagai berikut:

Tabel 3

Apakah syarat ujian komprehensif sudah tepat

\begin{tabular}{|l|c|c|c|}
\hline No. & Pilihan Jawaban & Frekuensi & Presentase (\%) \\
\hline 1. & Ya & 15 & $100 \%$ \\
2. & tidak & - & $0 \%$ \\
3. & Kurang setuju & - & $0 \%$ \\
& & & $100 \%$ \\
\hline
\end{tabular}

Tabel tersebut menggambarkan pandangan mahasiswa yang melihat syarat yang ditetapkan sudah tepat, karena secara langsung dapat terpenuhi jika mahasiswa menempuh jalur yang telah ditetapkan dalam rangka mencapai gelar Sarjana atau menyelesaikan studinya. Terlebih lagi ujian komprehensif dilaksanakan setelah skripsi dalam proses dan mahasiswa mendaftar saat menjelang wisuda, jadi sangat emudahkan mahsiswa.

b. Prosedur Pelaksanaannya

Adapun prosudur yang ditempuh setelah syarat terpenuhi bagi mahasiswa sudah diketahui sebagai gambaran yang terdapat dalam tabel sebagai berikut:

Tabel 4

Apakah prosedur ujian komprehensif sudah anda ketahui ?

\begin{tabular}{|l|c|c|c|}
\hline No. & Pilihan Jawaban & Frekuensi & Presentase (\%) \\
\hline 1. & Ya & 15 & $100 \%$ \\
2. & tidak & - & $0 \%$ \\
3. & Kurang setuju & - & $0 \%$ \\
& & & $100 \%$ \\
\hline
\end{tabular}

Melihat tabel tersebut, dapat dipahami sesungguhnya mahasiswa sudah mengetahui prosedur pelaksanaan ujian komprehensif, sehingga tidak ada yang 
menyulitkan bagi mereka. Untuk jelasnya dapat dilihat gambaran posedur ujian komprehensif sebagai berikut:
a) Mahasiwa mengecek nilai tentamen untuk mendapatkan keterangan bebas semester.
b) Mahasiswa melakukan tes baca tulis al-Qur'an di hadapan ketua Jurusan atau Sekretaris Jurusan.
c) Mahasiwa meminta keterangan dari pembimbing sebagai bukti bahwa Skripsinya sementara diperiksa oleh pembimbing.
d) Verifikasi adiministrasi oleh Kasubag akademik.
e) Penentuan Penguji Komprehensif
f) Pembuatan SK Penguji
g) Penerbitan SK.
h) Ujian

Jadi, setelah persyaratan terpenuhi, mahasiswa ke Kasubag akademik untuk mendaftar dan mendapatkan penguji. Ernawati mengatakan; setelah mahasiswa membawa syarat-syarat ujian komprehensif, dia melanjutkannya ke pembantu Dekan bidang akademik, karena dialah yang menentukan penguji komprehensif setiap mahsiswa. Setelah itu dibuatkanlah SK. Adapun waktu dibutuhkan dalam penerbitan SK penguji komprehensif tergantung pimpinan, artinya; jika pimpinan ada yakni Pembantu Dekan bagian akademik dan Dekan ada maka satu hari SK bisa selesai, akan tetapi jikaa pimpinan tidak ada berarti harus menunggu. Bila SK sudah selesai akan diserahkan kepada mahasiswa kemudian mahasiswa membawa langsung ke dosen yang ditunjuk dan sekaligus berkonsultasi kapan di lakasanakan ujian komprehensif. ${ }^{16}$

Setelah tiba waktu yang telah disepakati oleh mahasiswa dengan pengujinya maka dilaksanakanlah ujian komprehensif. Akan tetapi, terkadang mahasiswa disuru mengulang kembali manakala apa yang ditanyakan terkait dengan materi tersebut tidak dapat dijawab dengan menentukan waktu yang luang bagi dosen. Bukan berarti kita penguji mempersulit mahasiswa, melainkan kita menaruh harapan dengan ujian komprehensif mahasiswa mempunyai bekal pengetahuan tentang disiplin ilmu yang dimiliki, karena mereka sudah mau selesai. Itulah sebabnya, sehingga ada beberapa mahasiswa yang ujian komprehensif berulang kali. ${ }^{17}$

c. Materi Ujian Komprehensif.

Ada tiga Materi pokok yang akan diujikan dalam ujian komprehensif yang terdapat di prodi Ilmu Akidah yaitu;

- Filsafat yang meliputi Pengantar Filsafat, Filsafat Islam Klasik, Filsafat Islam Modern, dan Filsafat Barat.

\footnotetext{
${ }^{16}$ Wawancara Kabag Akademik Fakultas Ushuluddin dan Filsafat UIN Alauddin Makassar, hari Rabu 20 Agustus 2014.

${ }^{17}$ Wawancara Abdullah salah satu penguji komprehensif Filsafat Islam, hari Senin 25 Agustus 2014
} 
- Teologi Islam; meliputi; Pengantar Teologi Islam, aAliran-aliran Kalam dan Perbandingan teologi Modern

- Tafsir dan Hadis meliputi; Ulumul Qur'an, Ulumul Hadis, Tafsir Dan Hadis Melihat materi ujian Komprehensif tersebut, sangat banyak sekali, tetapi sesungguhnya, bukan hal yang baru lagi, hanya bersifat pengulangan saja terhadap apa yang sudah mereka pelajari. Jika mahasiswa saat mengikuti perkuliahan disemester awal memahami dengan baik materi-materi tersebut, pastilah tidak sulit mempelajarinya, karena bagaimanapun banyak jika sudah pernah didengar pastila saat membaca kembali akan teringat apa yang pernah didengar walaupun tiak secara keseluruhan. Hal ini semakin jelas setelah kita lihat jawaban mahasiswa dalam tabel sebagai berikut:

Tabel 5

Apakah materi-materi ujian komprehensif sudah pernah dipelajari ?

\begin{tabular}{|l|c|c|c|}
\hline No. & Pilihan Jawaban & Frekuensi & Presentase (\%) \\
\hline 1. & Ya & 15 & $100 \%$ \\
2. & tidak & - & $0 \%$ \\
3. & kurang tahu & - & $0 \%$ \\
\hline & & - & $100 \%$ \\
\hline
\end{tabular}

Justru jika ada yang mengatakan belum pernah mempelajari materi yang akan diujikan dalam ujian komprehensif berarti ada mata kuliah yang belum dilulusi dan tidak boleh mendaftar ujian komprehensif apalagi untuk ikut ujian. Hanya saja waktu yang digunakan untuk mempersiapkan ujian tidak semuanya sama, seperti yang tergambar dalam table sebagai berikut:

Tabel 6

Berapa hari yang saudara gunakan untuk mempersiapkan ujian satu mata kuliah ujian?

\begin{tabular}{|l|c|c|c|}
\hline No. & Pilihan Jawaban & Frekuensi & Presentase (\%) \\
\hline 1. & Satu minggu & 2 & $17 \%$ \\
2. & Dua minggu & 13 & $83 \%$ \\
3. & Di atas tiga minggu & - & $0 \%$ \\
& & - & $100 \%$ \\
\hline
\end{tabular}

Dengan adanya variasi penentuan waktu mempelajari materi ujian komprehensif diakibatkan tingkat pengetahuan dan kemampuan mahasiswa yang bervariasi. Meskipun demikian pada umumnya mengatakan hanya dua minggu seperti yang terlihat dalam tabel di atas. Ini menunjukkan bahwa pengetahuan mahasiswa tentang materi ujian komprehensif masih tersisa dari perkuliahan yang dilalui.

Sekalipun mahasiswa diberi waktu unntu belajar tetap saja ada yang datang tidak memiliki kesiapan pengetahuan untuk diuji, seperti yang diungkapkan oleh bapak $\mathrm{H}$. Abd. Kadir Saile bahwa mahasiswa yang datang ujian komprehensif ada yang tidak siap 
ujian dalam arti tidak yang ditahu, walaupun sebelumnya saat datang membawa SK sudah diberi tahu hal-hal yang harus dipelajari. Setelah tiba waktu yang disepakati untuk ujian, dia datang dengan pengetahuan yang sama saat pertama, sehingga kita kembali menjelaskan secara rinci tentang Ilmu Klam/Pengantar Teologi Islam, tidak jauh beda dengan memberikan kuliah kembali, setelah itu baru kita tanya untuk mengetahui tingkat pemahaman terhadap apa yang kita jelaskan. Terkadang juga kita suru catat, kemudian disuru kembali pelajari apa yang dicatat, kemudian datang kembali pada waktu yang disepakati untuk ujian. ${ }^{18}$

Jika melihat materi-materi tersebut sangat menunjang kompetensi utama yang akan dicapai oleh lulusan Prodi Ilmu Aqidah yaitu:

- Memiliki kemampuan akademik dan profesional dalam bidang pemikiran aqidah/teologi, sehingga dapat memberikan penjelasan secara tertulis, lisan maupun tindakan tentang aqidah/teologi.

- Memiliki kemampuan menjelaskan tentang pemahaman Islam yang insklusifpluralistik kepada masyarakat muslim dalam upaya mewujudkan masyarakat toleran dan dialogis. ${ }^{19}$

d. Biaya

Mengenai pembiayaan ujian komprehensif mulai dari pendaftaran sampai ujian tidak dibebankan kepada mahasiswa yang akan ujian komprehensif, sekalipun dosen yang menguji diberi honor. Honor penguji dibebankan pada anggaran APBN yang dicairkan setiap habis wisuda.

1. Kendala Yang Dihadapi Dalam Ujian Komprehensif.

Jawaban mahasiswa dari pertanyaan tentang kendala yang dihadapi dalam ujian komprehensif adalah

$>$ Tidak menguasai materi yang diujikan

$>$ Merasa gugup atau grogi

$>$ Kesulitan menentukan waktu yang tepat untuk ujian, karena harus menyesuaikan waktu penguji. ${ }^{20}$

$>$ Kurang referensi

Untuk kendala yang pertama, semua mahasiswa mengatakan tidak mampu menguasai materi komprehensif. Sementara kendala yang kedua adalah 2 orang, dan kendala yang ketiga adalah 10 orang. Adapun yang mengemukakan kurang referensi hanya lima orang. Perbedaan tersebut menujukkan kemampuan dan perhatian mahasiswa terhadap mata kuliah yang akan diujikan dalam ujian komprehensif pada saat menerima perkuliahan tersebut di kelas, karena hampir semua pengajar untuk mata kuliah tersebut memperkenalkan literatur-literatur atau referensi yang dijadikan rujukan dan bahkan diaanjurkan bagi mahsiswa untuk memilikinya. Tidak hanya itu, dingatkan

\footnotetext{
${ }^{18}$ Wawancara dengan bapak H. Abd. Kadir Saile, salah seorang penguji komprehensif untuk mata kuliah Teologi Islam, Rabu 27 Agustus 2014

${ }^{19}$ Lihat panduan Akademik

${ }^{20}$ Dokumen jawaban mahasiswa
} 
pula kepada mahsiswa bahwa mata kuliah tersebut akan menjadi bahan unjian komprehensif, sehingga mereka harus mempelajari dengan baik dan harus selalu diulang supaya tidak menemukan kesulitan saat akan ujian komprehensif.

2. Manfaat yang diperoleh dalam Ujian Komprehensif.

Jika diperhatikan uraian-uraian di atas, manfaat yang diperoleh mahasiswa dari ujian komprehensif pastilah ada dengan melalui usaha yang dilakukan oleh mahasiswa dalam mempersiapkan diri ujian komprehensif dilakukan secara sungguh-sungguh, mulai dari mencari literatur sampai ujian pastilah ada yang diketahui sekalipun hanya sedikit. Seperti jawaban mahasiswa yang mengatakan ya saat ditanya tentang adakah manfaat dalam ujian komprehensif. Adapun manfaat yang dimaksud adalah sebagai berikut:

- Menambah pengetahuan dan wawasan mahasiswa tentangmateri-materi pokok mata kuliah pokok Jurusan dan Prodi. Ada beberapa indikator yang mendukung manfaat pertama ini antara lain:

- Dilihat dari segi nilai yang diperoleh mahasiswa yang ujian komprehensif.

- Ada 15 mahasiswa dapat dilihat hasil yang dicapai antara nilai B dan A, bahkan jika diperesentasikan sekitar $75 \%$ dapat nilai A.

- Indikator yang lain adalah dilihat dari jawaban mahasiswa yang mengakui adanya manfaat dari ujian komprehensif.

Salah seorang penguji komprehensif mengatakan; jika mahasiswa yang ditanya tidak mampu menjawab pertanyaan yang diajukan maka kita yang akan membekali mahasiswa dengan materi inti atau pokok dari mata kuliah tersebut, kemudian kita menyuruh kembali mengulang, sehingga ada bekal mereka saat keluar atau menjadi Sarjana. $^{21}$

- Mengulang dan mempermntap kembali mata kuliah penting dari Fakultas dan Jurusan.

- Menguji kemampuan yang dimiliki oleh mahasiswa

- Mudah diingat.

1. Pelaksanaan ujian komprehensif dimulai dengan mempersiapkan syarat-syarat sebagai berikut::

a. Mahasiwa mengecek nilai tentamen untuk mendapatkan keterangan bebas semester.

b. Mahasiswa melakukan tes baca tulis al-Qur'an di hadapan ketua Jurusan atau Sekretaris Jurusan.

c. Mahasiwa meminta keterangan dari pembimbing sebagai bukti bahwa Skripsinya sementara diperiksa oleh pembimbing.

Setelah syarat-syarat terpenuhi langkah selanjutnya adalah:

a. Verifikasi adiministrasi oleh Kasubag akademik.

\footnotetext{
${ }^{21}$ Wawancara dengan H. Abd. Kadir Saile, hari Rabu 27 Agustus 2014
} 


\section{b. Penentuan Penguji Komprehensif \\ c. Pembuatan SK Penguji \\ d. Penerbitan SK penguji}

Setelah SK terbit, mahasiswa membawa SK tersebut ke dosen penguji, sekaligus membicarakan penentuan waktu untuk ujian. Di samping itu, mahasiwa meminta bahan materi yang akan diujikan. Pelaksanaan ujian dilakukan pada waktu yang sudah disepakati secara bersama oleh dosen dan mahasiswa.

2. Kendala yang dihadapi oleh mahasiswa dalam ujian komprehensif

a. Kurang mengusai materi yang akan diujikan. Ini dapat terjadi jika melihat waktu yang dipersiapkan bagi mahsiswa untuk ujian komprehensif pada umumnya dua mingggu untuk secara keseluruhan materi yang akan diujikan, seperti yang tergambar dalam tabel sebelumnya. Melihat materi yang begitu padat dapat dimaklumi jika mahasiswa mengatakan tidak dapat menguasai semua materi dengan persiapan dua minggu saja, kecuali jika dua minggu permata kuliah sangat memungkinkan dapat menguasai materi tersebut.Dari tiga meteri yang akan diujikan, Tafsir/ Hadislah yang mereka rasakan sangat kesulitan mempelajari.

b. Merasa Gugup.. Kesulitan ini hanya dikemukakan dua orang. Hal ini terkait dengan skill mahasiswa itu sendiri, tidak semuanya mampu mengemukakan apa yang diketahui didepan orang lain, jangankan dosen sesama temannya saja gugup apalagi terhadap penguji. Mahasiswa yang semacam itu sudah terbaca saat belajar di kelas, teman-teman sekelasnya aktif bertanya atau mengemukakan pendapatnya, sementara mereka diam saja.

c. Kesulitan menentukan waktu yang tepat untuk ujian, karena harus menyesuaikan waktu penguji. Hal ini sering terjadi, karena dosen tidak hanya mengajar, akan tetapi dituntut juga untuk melakukan penelitian dan pengabdian masyarakat. Pengajaran, penelitian dan pengabdian masyarakat sudah terjadwal, kemudian mahasiswa datang membawa SK kepada penguji dan sekali membicarakan kesiapan waktu penguji, tentunya penguji harus melihat waktu mereka, terlebih jika penguji tersebut adalah pejabat, sangat sulit sekali mencari waktu kosong. Terkadang sudah disepakati, tetapi tiba-tiba mendapat tugas, sehingga waktu yang sudah disepakati batal dan harus dibicarakan ulang.

d. Kurangnya referensi tentang mata kuliah yang diujikan dalan ujian komprehensif. Kendala ini sesungguhnya tidak dapat dijadikan alasan yang cukup signifikan, sebab dari awal sudah dianjurkan kepada mereka untuk memiliki buku minimal satu buah untuk setiap mata kuliah. Di samping itu, perpustakaan saat ini selain ada di Universitas, juga sudah ada di Fakultas. Cukup membantu mahsiswa dalam memperlancar perkuliahan mereka. Untuk mata kuliah yang diujikan di ujian komprehensip jika diperhatikan buku-buku yang ada di perpustakaan Fakultas Ushuluddin dan Filsafat cukup untuk 
membantu mereka, walaupun tidak sebanyak yang ada di Perpustakaan Universitas.

3. Manfaat yang diperoleh dalam ujian komprehensif adalah:

a. Menambah pengetahuan dan wawasan mahasiswa tentang materi-materi pokok mata kuliah pokok Jurusan dan Prodi. Dengan indikator:

1) Dilihat dari segi nilai yang diperoleh mahasiswa yang ujian komprehensif antara A dan B.

2) Pengakuan dari mahasiswa.

3) Mengulang dan mempermantap kembali mata kuliah penting dari Fakultas dan Jurusan.

4) Menguji kemampuan yang dimiliki oleh mahasiswa, sekaligus dimaksudkan mengetahui kompotensi yang dimiliki oleh mahasiswa yang akan menjadi sarjana atau menyelesaikan studinya. Bagaimanapun juga hal ini sangat dibutuhkan dalam rangka mempersiapkan mereka dengan kebutuhan masyarakat atau lapangan pekerjaan yang tersedia. Dengan memiliki kompotensi yang baik akan memudahkan mendapatkan lapangan pekerjaan, sehingga tidak terjadi pengangguran yang banyak.

5) Mudah mengingat pengetahuan yang diperoleh. Hal ini diakarenan; mahasiswa baru mendaftar ujian komprehensif saat skripsi mereka sudah rampung, sehingga tidak lama setelah usai ujian komprehensif mereka munaqasyah, sehingga saat jadi alumni ilmu mereka terkat dengan mata kuliah yang diujikan dalam komprehensif akan diingat.

\section{KESIMPULAN}

1. Pelaksanaan ujian komprehensif dimulai dengan mempersiapkan syarat-syarat sebagai berikut::

Mahasiwa mengecek nilai tentamen untuk mendapatkan keterangan bebas semester, kemudian melakukan tes baca tulis al-Qur'an di hadapan ketua Jurusan atau Sekretaris Jurusan, dan keterangan dari pembimbing sebagai bukti bahwa Skripsinya sementara diperiksa.

2. Kendala yang dihadapi oleh mahasiswa dalam ujian komprehensif

a. Mahasiswa kurang mengusai materi yang akan diujikan, karena waktu yang dipersiapkan oleh mahasiswahat sangat kurang sementara materi yang haus dipelajari sangat banyak

b. Mahasiswa merasa gugup..

c. Kesulitan menentukan waktu yang tepat untuk ujian, karena harus menyesuaikan waktu penguji.

d. Kurangnya referensi tentang mata kuliah yang diujikan dalan ujian komprehensif. Kendala ini sesungguhnya tidak dapat dijadikan alasan yang cukup signifikan, sebab dari awal sudah dianjurkan kepada mereka untuk memiliki buku minimal satu buah untuk setiap mata kuliah.

3. Manfaat yang diperoleh dalam ujian komprehensif adalah: 
a. Menambah pengetahuan dan wawasan mahasiswa tentang materi-materi mata kuliah kompotensi Jurusan dan Prodi. Dengan indikatork:

- Dilihat dari segi nilai yang diperoleh mahasiswa yang ujian komprehensif antara A dan B.

- Mengulang dan mempermantap kembali mata kuliah kompotensi Fakultas dan Jurusan.

b. Menguji kemampuan yang dimiliki oleh mahasiswa, sekaligus dimaksudkan mengetahui kompotensi yang dimiliki oleh mahasiswa yang akan menjadi sarjana atau menyelesaikan studinya.

c. Mudah mengingat pengetahuan yang diperoleh.

\section{DAFTAR PUSTAKA}

Abd. Muin Salim, Beberapa Aspek Metodologi Tafsir al-Qur'an (Ujung Pandang: Lembaga Studi Kebudayaan Islam, 1990), h. 24-25.

Departemen Pendidikan Nasional, Kamus Besar Bahasa Indonesia, Jakarta: Balai Pustaka, 2003.

Ine I Yousda Amiran \& Zainal Arifin, Penelitian dan Statistik Pendidikan, Jakarta: PT. Bumi Restu, Aksara.

James P. Spradley, Participation Observation, New York: Holt, Rinehart and Winston, 1990.

M. Ngalim Purwanto, Ilmu Pendidikan Teroritis dan Praktis, Bandung: PT Remaja Rosdakarya, 2009

Moleong, Lexy J., Metode Penelitian Kualitatif, Cet.VIII; Bandung: PT. Remaja Rosdakarya, 2000.

Muhammad bin Ali bin Muhammad, Irsyad al-Fuhuli Ila Tahqiq al-Haqq min Ilmi alUsuli, Beirut: Dar al-Fikr, t.t.

Surtrisno Hadi, Metodologi Reseach, Jakarta: UGM Press, 1980.

Panduan Akademik

Borang Akreditasi Ilmu Aqidah 